\title{
Narasi Hijrah: Sebuah Fenomena Living Qur'an pada Komunitas Biker Muslim Bengkulu
}

\author{
Ahmad Farhan \\ Institut Agama Islam Negeri Bengkulu \\ e-mail: ahmad.farhan@iainbengkulu.acid
}

\begin{abstract}
Al-Qur'an text that 'lives' in society as a phenomenon that is called the Living Qur'an. This paper aims to describe the views and understanding of the Bengkulu Muslim Biker Community on migrating and provide an overview of the practice of migrating in the Muslim Biker Community. This paper is field research that uses the Living Qur'an approach and phenomenology with qualitative descriptive methods. To obtain data, this research was conducted by observation, interview and documentation. The findings in this study are: First, this community was formed as a place to accommodate bikers to become better personal, including reducing the negative image in the community. Then the migration becomes necessary for the intended change. The hijrah understood by this community is change and movement. Namely changes and transfers from actions that are not in accordance with religious teachings to actions that can draw closer to God. Hijrah is also understood as passing away in the sense of leaving $k u f r$ and things that are not in accordance with religious teachings and passing away to the actual path. This meaning is in line with the understanding of Muslims in general. Second, as for the form of migrant practice in Bengkulu Biker Muslim community, researchers are limited to three things, namely 1). Perform prayers, departing from the reading and interpretation of QS. al-Baqarah /2: 43, QS. al-Ankabut /29: 45. 2). Love giving alms and giving alms based on QS. al-Baqarah /2:2, 110, 195 and 268. 3). Establish brotherhood and care for others based on QS. al-Hujurat /49: 10.
\end{abstract}

Keyword: Hijrah, Bikers, Living Qur'an

\begin{abstract}
Abstrak
Teks al-Qur'an yang 'hidup' dalam masyarakat sebagai fenomena itulah yang disebut Living Qur'an. Tulisan ini bertujuan untuk mendeskripsikan pandangan dan pemahaman Komunitas Biker Muslim Bengkulu terhadap hijrah dan memberikan gambaran praktek hijrah di Komunitas Biker Muslim. Tulisan ini merupakan data penelitian lapangan (Field Research) yang menggunakan pendekatan Living Qur'an dan fenomenologi dengan metode deskriptif kualitatif. Untuk mendapatkan data, penelitia ini dilakukan dengan cara observasi, wawancara dan dokumentasi. Adapun temuan dalan penelitian ini adalah,: pertama, komunitas ini dibentuk sebagai wadah untuk mengakomodir para biker menjadi pribadi lebih baik, termasuk mengurangi image negatif di masyarakat. Maka hijrah menjadi niscaya untuk perubahan yang dimaksud. Hijrah difahami oleh komunitas ini adalah perubahan dan perpindahan. Yakni perubahan dan perpindahan dari perbuatan yang tidak sesuai dengan ajaran agama menuju perbuatan yang dapat mendekatkan diri mereka kepada Allah. Hijrah juga difahami sebagai berpulang dalam arti meninggalkan kekufuran dan hal-hal yang tidak sesuai dengan ajaran agama dan berpulang ke jalan yang sebenarnya. Pemaknaan ini sejalan dengan pemahaman umat Islam pada umumnya. Kedua, adapun bentuk praktek hijrah komunitas Biker Muslim Bengkulu dibatasi peneliti pada tiga hal saja, yaitu 1). Melaksanakan shalat, berangkat dari pembacaan dan pemaknaan QS. al-Baqarah/2: 43, QS. al-Ankabut/29: 45. 2). Gemar Bersedekah dan menunaikan zakat yang didasarkan pada QS. al-Baqarah/2: 2, 110, 195 dan 268. 3). Menjalin Persaudaraan dan peduli sesama berbasiskan QS. al-Hujurat/49: 10.
\end{abstract}

Keyword: Hijrah, Bikers, Living al-Qur'an. 


\section{Pendahuluan}

Pengalaman dalam berinteraksi dengan al-Qur'an umumnya menghasilkan pemahaman dan penghayatan terhadap ayat-ayat al-Qur'an tertentu secara atomistik. ${ }^{1}$ Pemahaman dan penghayatan individual yang diungkapkan serta dikomunikasikan secara verbal maupun prilaku biasanya punya pengaruh kepada individu lain yang pada gilirannya dapat mengkosntruk kesadaran kolektif yang juga menciptakan tindakan dan perilaku dalam kehidupannya. ${ }^{2}$ Menurut Syamsuddin bahwa "Teks alQur'an yang 'hidup' dalam masyarakat itulah yang disebut Living Qur'an. Dalam bahasa lain, fenomena ini merupakan sikap dan variasi respon muslim terhadap al-Qur'an.

Sebagai petunjuk hidup, al Qur'an juga menjadi sumber inspirasi terhadap perubahan prilaku seseorang atau

\footnotetext{
$\begin{array}{cl}1 & \text { Muhammad Chirzin, "Mengungkap } \\ \text { Pengalaman } & \text { Muslim Berinteraksi dalam al- }\end{array}$ Qur'an" dalam Metodologi Penelitian Living al-Qur'an dan Hadis, ed Sahiron Syamsuddin, (Yogyakarta: Teras, 2007), hal. 12.

2 Dalam realitas sosial kehidupan muslim, tindakan yang dimaksud penulis dapat disaksikan begitu dekat oleh kita. Pengalaman berinteraksi dengan alQur'an terlihat begitu beragam dari sekedar membaca alQur'an baik secara sendiri maupun berjamaah (baca: komunitas), kelompok penggiat kajian tafsir al-Qur'an, penghafal al-Qur'an, mengusir makhluk halus dengan alQur'an, praktek ruqyah, hingga menjadikan ayat-ayat alQur'an tertentu dan menjadikannya sebagai hiasan rumah, hiasan masjid dan sebagainya. Semua yang dicontohkan tersebut merupakan sebagian dari bentuk terapan interaksi muslim dengan al-Qur'an.

3 Syamsudin, S., "Ranah-ranah Penelitian dalam Studi al-Qur'an dan Hadis" dalam M. Mansyur
}

kelompok untuk menjadi lebih baik dari kondisi sebelumnya. Pembacaan terhadap al-Qur'an sebagai petunjuk ini merupakan salah satu bentuk dari pemaknaan alQur'an. Heddy Sri Ahimsa dalam The Living al-Qur'an: Beberapa Perspektif Antropologit mengklasifikasikan beberapa pemaknaan terhadap al-Qur'an diantaranya al-Qur'an sebagai kita petunjuk $\left(\right.$ huda). ${ }^{5} \quad$ Berbicara tentang penelitian Living Qur'an telah banyak dilakukan seperti Muhammad Misbah yang menulis tentang Living Qur'an di Instansi Kesehatan: Fenomena "Gerakan Membaca Al-Quran Sebelum Bekerja" di Rumah Sakit Islam Sultan Agung Semarang. Hasil penelitian menunjukkan bahwa para karyawan Rumah Sakit Islam Sultan Agung Semarang memaknai gerakan membaca al-Quran sebelum bekerja dengan dua pemaknaan yakni makna zahir dan makna batin. Makna zahir mencakup pemahaman mereka yang mengatakan bahwa membaca al-Quran

dkk., Metodologi Penelitian Living Qur'an dan Hadis, (Yogyakarta: TH. Press, 2007), hal. xiv. 4 Menurut Heddy Shri Ahimsa bahwa Kajian The Living al-Qur'an di sini kemudian memang lebih dekat dengan kajian-kajian ilmu sosial-budaya seperti antropologi dan sosiologi, di mana peneliti tidak lagi mempersoalkan kebenaran sebuah tafsir atau perlakuan terhadap al-Qur'an, karena tujuan penelitian bukanlah 'mengadili' atau 'menilai' sebuah pemaknaan dan pengejawantahannya dalam kehidupan, tetapi memahami, memaparkan dan menjelaskan gejala-gejala tersebut sebaik-baiknya. Lihat Heddy Shri Ahimsa, The Living al-Qur'an: Beberapa Perspektif Antropologi, dalam Jurnal Walisongo, Volume 20, Nomor 1, Mei 2012, hal. 258. 
sebagai suatu kewajiban, kebutuhan, dan rutinitas. Sedangkan makna batin meliputi tilawah sebagai motivasi hidup, penenang hati, sarana intropeksi diri, dan tabungan amal di akhirat kelak. ${ }^{6}$

Implikasi dari pembacaan dan pemaknaan al-Qur'an sebagaimana dimaksud, maka terdapat perubahan perilaku masyarakat ke arah lebih baik dalam kehidupannya yang biasa dikenal dengan sebutan hijrah. Terkait dengan fenomena hijrah dan komunitasnya, penulis juga melakukan literature review pada penelitian Dhita Prasanti dan Sri Reti Indriani yang melakukan riset dengan judul Konstruksi Makna Hijrah bagi Komunitas Let's Hijrah dalam Media Sosial Line. Penelitian ini selanjutnya mendeskripsikan konstruksi makna hijrah pada komunitas ini dengan metode etnografi virtual. Dari penelitian ini ditemukan bahwa makna hijrah meliputi 1) Hijrah disepakati sebagai sebagai tujuan hidup untuk melakukan perubahan menuju hal yang lebih baik sesuai ajaran Islam. 2) Hijrah harusi ditunjukkan dalam konteks verbal

5 Dalam QS. Al-Baqarah/2: 2 disebutkan bahwa al-Qur'an adalah kitab yang tidak ada keraguan di dalamnya, petunjuk bagi orang yang bertaqwa.

6 Muhammad Misbah, Living Qur'an di Instansi Kesehatan: Fenomena "Gerakan Membaca Al-Quran Sebelum Bekerja" di Rumah Sakit Islam Sultan Agung Semarang. OJS, "Hermeneutik" Jurnal Ilmiah Seputar Kajian al-Qur'an dan Tafsir, Prodi Ilmu al-Qur'an dan Tafsir STAIN Kudus. Lihat di http:/ /journal.stainkudus.ac.id. maupun konteks non verbal oleh setiap anggota komunitas Lets Hijrah. 3). Hijrah juga dimaknai sebagai pembentukan identitas diri setiap anggota komunitas Let's Hijrah. $^{7}$

Begitu juga dengan apa yang diteliti oleh Annisa Novia Sari dan Adi Bayu Mahadian yang menulis tentang Perilaku Komunikasi Pelaku Hijrah (Studi Fenomenologi Pelaku Hijrah dalam Shift Gerakan Pemuda Hijrah Kota Bandung). Penelitian ini dilakukan untuk mengetahui perilaku komunikasi dengan melihat motif sebagai dorongan, makna dan interaksi yang dipertukarkan seseorang yang berhijrah dengan lingkungannya yang dapat membentuk perilaku untuk melaksanakan tindakan tertentu. Metode yang digunakan adalah metode kualitatif dengan pendekatan fenomenologi dan paradigma intepretif. Hasil penelitian ini adalah ada 4 motif yang membuat seseorang berhijrah yaitu dorongan masa lalu, dorongan teman, ingin mempengaruhi orang lain dan dorongan masa depan. Perilaku komunikasi juga dapat dilihat

7 Dhita Prasanti dan Sri Seti Indriani, Konstruksi Makna Hijrah bagi Komunitas Let's Hijrah dalam Media Sosial Line, dalam “al-Izzah" Jurnal Hasil-hasil Penelitian, IAIN Kendari, Volume 14, Nomor 1 (Mei 2019), hal. 106119. 
berdasarkan interaksi yang dipertukarkan oleh pelaku hijrah. ${ }^{8}$

Tentunya fenomena hijrah juga bisa dianggap sebagai komodifikasi agama seperti yang ditulis oleh Afina Amna dengan judul Hijrah Artis sebagai Komodifikasi Agama. Penelitian ini ingin melihat lebih jauh apakah fenomena hijrah di kalangan artis termasuk dalam komodifikasi agama serta bagaimana masyarakat memaknai hijrah yang dilakukan para artis. Metode yang digunakan adalah penelitian kualitatif dengan observasi lapangan. Untuk teori yang digunakan adalah teori agen struktur dan agenda setting untuk mengetahui pengaruh terhadap dua hal tersebut. ${ }^{9}$

Sementara itu, penelitian ini berusaha untuk menjawab pertanyaan tentang fenomena living Qur'an dengan narasi bagaimana pemahaman hijrah dan pengalamannya dalam praktek keagamaan komunitas biker Muslim Bengkulu.

\section{Metode Penelitian}

Tulisan ini memfokuskan kepada narasi hijrah dalam pratek keagamaan komunitas Biker Muslim Bengkulu Hijrah. Penelitian ini merupakan jenis penelitian lapangan (Field Research) yang menggunakan metode deskriptifkualitatif. ${ }^{10}$ Metode penelitian kualitatif sering disebut metode penelitian naturalistik karena penelitiannya dilakukan pada kondisi yang alamiah, disebut juga sebagai metode etnografi. Penelitian kualitatif dilakukan pada objek alamiah yang berkembang apa adanya, tidak dimanipulasi oleh peneliti dan kehadiran peneliti tidak begitu mempengaruhi dinamika pada objek tersebut. Penelitian kualitatif instrumennya adalah peneliti itu sendiri. Menjadi instrumen, maka peneliti harus memiliki bekal teori dan wawasan luas, sehingga mampu bertanya, menganalisis, memotret, dan mengkonstruksi situasi sosial yang diteliti menjadi lebih jelas dan bermakna. ${ }^{11}$

UIN Sunan Kalijaga Yogkarta, Volume 13, Nomor 2, April 2019, hal. 331-350.

10 Nyoman Kutha Ratna, Teori, Metode, dan Teknik Penelitian Sastra: Dari Strukturalisme hingga Poststrukturalisme (Yogyakarta: Pustaka Pelajara, 2006), h. 5354. Metode ini juga menyelidiki dengan menuturkan, menganalisa data-data dan menjelaskannya. Hermawan Warsito, Pengantar Metode, (Jakarta: Gramedia, 1993). Lihat juga Anton Baker, Metode-Metode Filsafat (Jakarta: Ghalia Indonesia, 1994), hal. 17.

11 Moleong, Lexy J, Metodologi Penelitian Kualitatif, (Bandung: Remaja Rosyada Karya, 2005), hal. 3. 
Untuk mendapatkan jawaban dari rumusan masalah, penelitian ini menggunakan pendekatan living Qur'an dan fenomenologi. ${ }^{12}$ Yaitu peneliti mendeskripsikan serta menganalisa fenomena living al-Qur'an (al-Qur'an yang hidup) yang terjadi di masyarakat terkait dengan makna hijrah dalam praktek keberagamaan komunitas Biker Muslim Bengkulu. ${ }^{13}$ Dalam pendekatan living Qur'an, sebuah pembacaan terhadap ayatayat al-Qur'an bisa melahirkan pemaknaan tertentu yang kemudian menjadi praktek kehidupan (living) sehingga al-Qur'an itu menjadi hidup dalam interaksi sosial keagamaan.

Dalam penelitian ini, informan penelitian ditentukan sebanyak delapan orang dengan teknik purpossive. sampling Teknik ini digunakan dengan cara mengambil informan sesuai kebutuhan penelitian dengan kriteria yang ditentukan oleh penulis. Sedangkan data dikumpulkan dengan cara 1). Observasi, Yaitu observasi yang dilakukan terhadap tempat terjadi atau berlangsungnya

12 Istilah fenomenologi berasal dari bahasa Yunani Pahainomenon yang secara harfiah berarti "gejala" atau "apa yang telah menampakkan diri" sehingga nyata bagi kita. Fenomenologi sebagai metode berfikir ilmiah, merupakan cabang dari aliran filsafat, yaitu filsafat eksistensial. Lihat Imam Suprayogo, Metodologi Penelitian Sosial-Agama, (Bandung: Remana Rosyda Karya, 20030), hal. 102.

13 Menurut Moleong, para fenomenolog percaya bahwa pada makhluk hidup, tersedia berbagai cara untuk menginterpretasikan pengalaman melalui interaksi berbagai aktivitas yang menjadi praktek keagamaan komunitas Biker Muslim Bengkulu, sehingga observer bersama objek yang diteliti. 2). Wawancara. Dalam penelitian ini, peneliti menggunakan teknik wawancara mendalam (in-depth interview). ${ }^{14}$ Dalam teknik ini, peneliti terlibat secara intensif dengan setting penelitian dan melakukan tanya jawab yang terbuka serta mengalir sesuai kebutuhan data yang akan diperoleh. 3). Dokumentasi. Teknik ini merupakan bagian dari mencari data dan atau mengumpulkan sumber-sumber dokumen yang dibutuhkan untuk memperkuat hasil penelitian dari observasi maupun wawancara. Dokumen yang dimaksud bisa berupa gambar, tulisan, lokasi, materi foto yang mendukung data penelitian.

\section{Temuan dan Pembahasan Penelitian}

\section{Eksistensi Komunitas Biker Muslim} Bengkulu

Komunitas Biker Muslim Bengkulu yang juga dikenal BMB (baca: Biker Muslim Bengkulu) adalah sekumpulan pria muda dan dewasa, single dan telah menikah,

dengan orang lain Moleong Lexy J, Meetodologi Penelitian Kualitatif..., hal. 18.

14 Yaitu suatu proses untuk mendapatkan informasi untuk kepentingan penelitian dengan cara dialog antara peneliti sebagai pewawancara dengan 
dengan berbagai profesi yang punya hobi sama yaitu bermotor. Bermotor yang dimaksud adalah orang-orang yang punya kecenderungan dengan menggunakan motor untuk melakukan touring atau secara bersamaan pada moment tertentu dan pada hari tertentu berdasarkan kesepakatan. Penggunaan istilah komunitas biker muslim ini untuk memberikan kesan positif masyarakat sejalan pandangan dan stigma negatif terhadap kelompok pria bermotor yang dikenal dengan sebutan geng motor.

Menurut Henly, salah satu inisiator berdirinya komunitas ini bahwa selama ini orang-orang yang berkelompok dalam mengendarai motor (baca: bikers) tidak jarang terkesan arogan, sombong, mabuk, melakukan kekerasan, dan berbagai aktivitas negatif lainnya. Maka untuk mengurangi atau bahkan menghilangkan kesan demikian, maka perlu diciptakan wadah bagi mereka yang suka bermotor atau ada kelompok yang punya komunitas motor tertentu untuk melakukan perubahan sikap dan melakukan yang baik serta meninggalkan kebiasaan

informan dlam konteks observasi partisipasi. Lihat Djam'an Satori, Metodologi...hal. 131. buruk. Selain itu diperlukan penanaman akidah dan pemahaman moralitas keagamaan yang baik.

Ditambahkan oleh Adi Sucipto selaku inisator yang kemudian dijadikan guru dalam komunitas ini menyatakan bahwa berdirinya komunitas ini merupakan satu ikhtiar dan medan dakwah bagi seseorang atau kelompok motor agar mau merubah dirinya ke arah yang lebih baik. Dengan begitu, ada keinginan menjadikan komunitas biker ini menjadi media mereka untuk hijrah sekaligus sebagai media untuk berdakwah. Kalau Biker Subuhan selama ini lebih identik dengan kegiatan shalat subuh berjamaah saja. Maka, komunitas Biker Muslim Bengkulu ingin lebih banyak hal yang bisa dilakukan sebagai upaya dan bentuk aktualisasi hijrah. Pada perjalanannya komunitas ini akrab disebutkan sebagai "Bikers Moslem Bengkulu Hijrah"

Dalam penjelasannya, Henli menambahkan bahwa filosofi jargon "My Hijrah is My Advanture". mengandung arti perubahan dari sisi kelam menuju sisi terang, yakni perubahan dari perilaku sebelumnya yang cenderung kurang baik seperti nakal, minum minumam 
keras hingga mabuk, tampil urakan, menggunakan narkoba dan tidak pernah sholat. Semua aktivitas yang jauh dari perintah agama ini ingin driubah menuju ke arah yang jauh lebih baik lagi dengan berpedoman kepada al-Qur'an dan hadis. Dengan begitu, proses untuk menuju ke arah yang lebih baik itulah yang dinamakan perjuangan dan petualangan menuju lebih baik. (advanture). ${ }^{15}$

Berdasarkan observasi peneliti bahwa komunitas ini memiliki keanggotaan sejumlah lebih kurang 50 orang dengan usia kisaran18-50 tahun. Aggota komunitas ini berasal dari latar belakang berbeda baik pelajar, mahasiswa, swasta, pegawai Bank dan PNS. Aktivitas yang dilakukan sepanjang ini adalah pengajian mingguan (baca: NGOPI: Ngobrol Perkara Iman) dengan mengundang beberapa tokoh agama sebagai nara sumbernya, Gerakan shalat subuh berjamaah di masjid secara random, mengunjungi anggota keluarga yang sakit, melakukan silaturrahim kepada tokoh tertentu, memberikan bantuan sosial ketika terjadi bencana dan melakukan donasi untuk rehab masjid atau Musholla. Adapun lokasi yang

15 Hasil wawancara Henly, Sabtu, 3 Agustus 2019 Pukul 20.55 Wib. biasa dijadikan tempat berkumpul untuk kajian adalah Sekretariat Biker Muslim Bengkulu di Jalan Fatmawati X Kelurahan Penurunan Kota Bengkulu atau rumah kediaman Henly. ${ }^{16}$

\section{Pembacaan dan Pemaknaan al-Qur'an}

Seperti yang disebutkan oleh Ahmad Rafiq, bahwa tujuan umat Islam dalam membaca al-Qur'an salah satunya untuk mendapatkan petunjuk atau hidayah.17 Sejalan dengan itu, Heddy Shri Ahimsa Putra, seorang pakar Antropologi UGM, menyebutkan ada banyak pemaknaan terhadap al-Qur'an yang tampak pada kehidupan masyarakat muslim. Salah satu tujuan pembacaan dan pemaknaan al-Qur'an yang dimaksud adalah adalah menjadikan al-Qur'an sebagai bacaan dan petunjuk dalam kehidupan.

Petunjuk adalah segala sesuatu yang dapat membawa manusia kepada sesuatu yang baik atau yang membuat seorang individu sampai pada suatu keadaan yang baik dan benar. Kalau dia tidak membawa manusia pada keadaan tersebut maka dia dikatakan

\footnotetext{
16 Diolah dari Hasil wawancara Henly, Sabtu, 3 Agustus 2019 Pukul 20.55 Wib.

17 Ahmad Rafiq, Pembacaan yang atomistic terhadap al-Qur'an Antara Penyimpangan dan Fungsi, Jurnal Studi Ilmu al-Qur'an dan Hadis, Vol. 5, No. 1 Januari 2004, hal. 4
} 
sebagai "penyesat" atau yang menyesatkan, yaitu segala sesuatu yang membuat seseorang tidak sampai pada keadaan yang dianggap baik dan benar, atau yang diinginkan. ${ }^{18}$

Dari hasil wawancara penulis, umumnya informan penelitian memaknai al-Qur'an sebagai petunjuk, pedoman, pegangan dalam kehidupan. Seperti yang disebutkan oleh Henli bahwa al-Qur'an adalah pegangan hidup manusia. Menjadi kewajiban setiap muslim untuk belajar al-Qur'an agar dapat membacanya dengan baik. Pemaknaan ini juga dikuti dengan pengetahuan hadis Nabi tentang keutamaan membaca alQur'an dan mempelajarinya. Hal ini menjadi pendorong bagi anggota komunitas Biker Muslim Bengkulu dalam memposisikan al-Quran sebagai kitab petujuk yang wajid dipedomani dalam kehidupan sehari-hari.

Ditambahkan oleh Iqbal bahwa kehidupan akan kacau jika tidak berpegang kepada al-Qur'an. Baginya al-Qur'an merupakan arah dan

${ }^{18}$ Heddy Shri Ahimsa Putra, The Living....., hal. 243. Hidayah difahami juga sebagai petunjuk Allah terhadap makhluknya tetnagn sesuatu yang mengandung kebenaran atau berharga dan membawa keselamatan. Dalam al-Qur'an, hidayah digunakan dalam arti penjelasan, petunjuk dan taufik. Hidayah dengan makna penjelasan mengacu pada dua hal: 1). Menjelaskan sesuatu yang baik serta membawa kepada kebenaran dan keselamatan. 2). Menjelasakan sesuatu yang buruk dan pegangan hidup. Begitupula pemaknaan al-Qur'an oleh Sutrisno yang menyebutkan bahwa kendati dirinya belum baik dalam membaca alQur'an, tapi dirinya menyakini bahwa al-Qur'an adalah petunjuk bagi orang beriman untuk keselamatan di dunia akhirat. Hal senada diutarakan oleh Berry bahwa al-Qur'an dimaknai sebagai aturan dalam hidup yang harus ditaati. Sedangkan Satrio memaknai al-Qur'an sebagai kitab inspirasi bagi umat Islam yang didalamnya mengandung banyak petunjuk bagi umat Islam. Pembacaan dan pemaknaan al-Qur'an seperti inilah yang kemudian menjadi pendorong komunitas biker Muslim Bengkulu untuk bersama-sama berproses menjadi lebih baik dalam hidup dengan merujuk pada alQur'an. Adanya pengakuan bahwa meski tidak pandai membaca alQur'an tapi tetap mau mempelajarinya dan akan berpegang pada petunjuk yang terkandung di dalamnya, menjadi sebuah spirit mereka dalam berhijrah.

membawa kepada kesesatan. Lihat Ensiklopedia Islam, (Jakarta: PT. Ichtiar Baru van Hoeve, 2001), hal. 541. 
3. Hijrah dalam Perspektif Komunitas Biker Muslim Bengkulu.

Dari hasil wawancara penulis, Subyek penelitian mengkorfimasikan bahwa hijrah secara umum adalah berubah ke arah yang baik dan meninggalkan keburukan. Dengan begitu niat berhijrah mengharuskan untuk belajar dan menambah pengetahun dalam beragama sehingga apa yang dilakukan dalam rangka hijrah mendapatkan kebaikan dan pahala dari Allah. Hijrah juga dimaknai oleh Informan sebagai spirit perubahan menuju kehidupan yang lebih baik dalam segala hal. Dengan hijrah tentunya ada perubahan yang ditunjukan baik secara fisik maupun non fisik, jasmani maupun rohani. Dengan begitu, kehidupan yang lebih baik, lebih nyaman, lebih damai bisa dirasakan sedikit demi sedikit, termasuk banyak bersilaturrahim dan beraktivitas yang bermanfaat. Memaknai hijrah sebagai upaya untuk berubah ke arah yang lebih baik, pindah dari kebiasan buruk sebelumnya kepada kebiasaan baik memang menjadi satu point yang lazim difahami banyak orang termasuk anggota Biker Muslim Bengkulu. Kebiasaan lama yang banyak dihabisan kepada hal yang cenderung tidak baik atau bahkan merusak, ditinggalkan sebagai konsekwensi dari keinginan melakukan hijrah. Termasuk apa yang difahami oleh informan lainnya bahwa hijrah baginya adalah perpindahan, yaitu pindah dari kebiasaan buruk menjadi lebih baik dari sebelumnya. Kebiasaan tidak shalat, malas berangkat ke masjid dan suka nonkrong disadarinya merupakan kebiasaan buruk. Oleh karenanya, berpindah dari kebiasan itu untuk menjadi lebih baik adalah pemahaman dan menjadi motivasi untu hijrah dan bergabung di komunitas Biker.

Menurut penulis, setiap informan memiliki perspektif yang mendekati sama terkait makna hijrah. Hijrah difahami sebagai perubahan dan perpindahan dari perbuatan yang tidak sesuai dengan ajaran agama menuju perbuatan yang dapat mendekatkan diri mereka kepada Allah. Seperti yang disebutkan oleh Henli bahwa hijrah secara umum adalah berubah ke arah yang baik dan meninggalkan keburukan. Sementara Andi menegaskan bahwa hijrah adalah berpindah tempat atau lingkungan yang selama ini menjauhkan diri kepada Allah menuju tempat dan lingkungan yang 
senantiasa mengigatkan dan

mendekatkan diri kepada Allah.

Pada aspek narasi dan terminologi, bahwa hijrah memang mudah untuk difahami termasuk informan penelitian yang notabene anggota Komunitas biker Muslim Bengkulu. Untuk itu, penulis merasa pemahaman yang mereka miliki secara substansi adalah benar, tinggal seberapa konsisten komunitas ini tetap pada jargonnya My Hijrah is My Advanture dan menamakan diri mereka dengan Biker Muslim Bengkulu Hijrah.

Karena hijrah secara fisik dan penampilan boleh jadi mudah untuk dilakukan, tapi menjadi istiqamah dengan keputusan yang diambil dengan segala konsekwensinya tentunya membutuhkan perjuangan, kesabaran dan keikhlasan ${ }^{19}$ dari setiap individu, tidak hanya bagi anggota komunitas ini, tapi bagi siapa saja dari yang menyatakan hijrah untuk

19 Niat yang lurus dan ikhlas semata-mata kepada Allah adalah salah satu kunci dalam melakukan kebaikan. Karena niat itulah yang akan jadi pembeda bagi sesorang ketika sedang berbuat baik dan akan selalu berbuat baik. Akankah sama dalam setiap kondisi, baik lapang maupun sempit, panas atau dingin. Bahwa setiap pekerjaan itu berkorelasi dengan apa yang diniatkan sebagai sabda Nabi bahwa setiap amalan tergantung niat, dan setiap perbuatan akan dibalas seperti apa yang diniatkan. Lihat hadis Muslim dalam bab Niat. menjadi pribadi yang baik dalam pandangan Allah.

Meski demikian, secara umum apa yang ditunjukkan dalam praktek keagamaan komunitas ini sebagai manifestasi dari hijrah adalah satu hal positif dan perlu diapresiasi. Adanya kegiatan dan program yang berkesinambungan dalam sosial keagamaan dan dibina oleh seorang ustad tentunya bisa menjadi kontrol mereka dalam menjaga niat hijrah.

4. Living Qur'an dalam Praktek Keagamaan di Komunitas Biker Muslim Bengkulu

a. Pemahaman dan Pengamalan Ayat tentang Shalat

Bahwa shalat merupakan kewajiban utama bagi umat Islam. Selain menjadi rukun Islam kedua (HR. Muslim), ${ }^{20}$ shalat juga merupakan sifat terpenting yang menentukan keimanan dan ketaqwaan seseorang (QS. AlAnfal/8: 2-5) ${ }^{21}$ serta penentu nasib

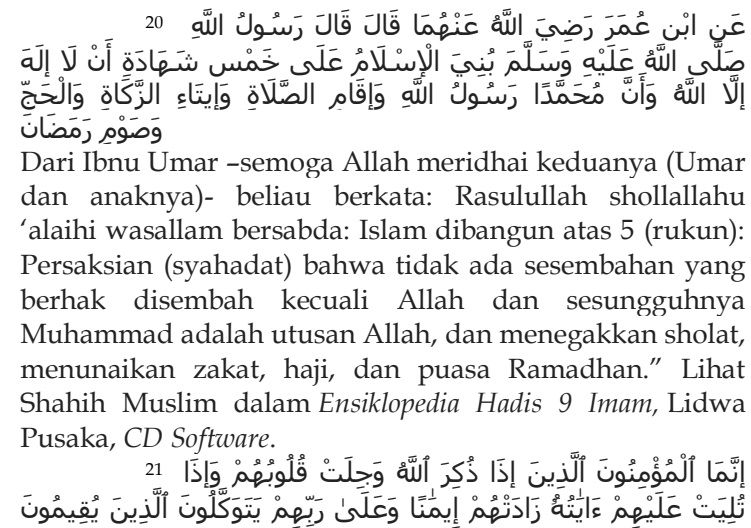


seseorang di alam akhirat (QS. Al-

Mudas\}s\}ir/74: 42-43).22

Menurut informan

penelitian ini, Henli misalnya, menyadari bahwa kewajiban sholat itu sangatlah penting bagi seorang muslim/mah. Apalagi bagi seorang bikers yang sering melakukan safar (perjalanan jauh).

Maka dengan menyakini dan melaksanakan kewajiban shalat, dalam perjalananpun tidak diperkenankan meninggalkan shalat. Karena seorang bikers tetap bisa melakukan shalat dengan cara jamak dan qashar. Menurutnya, bahwa Allah telah mewajibkan shalat dengan menyebutkan QS. Al-Baqarah/2: 43:

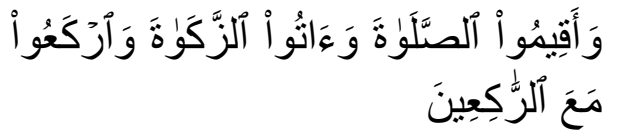

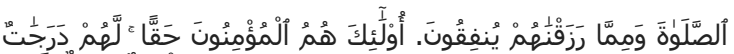

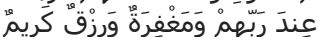

"Sesungguhnya orang-orang yang beriman ialah mereka yang bila disebut nama Allah gemetarlah hati mereka, dan apabila dibacakan ayat-ayat-Nya bertambahlah iman mereka (karenanya), dan hanya kepada Tuhanlah mereka bertawakkal. (yaitu) orang-orang yang mendirikan shalat dan yang menafkahkan sebagian dari rezeki yang Kami berikan kepada mereka. Itulah) orang-orang yang berciri khas seperti tadi (mereka orang-orang yang beriman dengan sebenar-benarnya) yang tidak diragukan lagi keimanannya. (Mereka akan memperoleh beberapa derajat ketinggian) kedudukan-kedudukan di surga (di sisi Tuhannya dan ampunan serta rezeki yang mulia) di surga" Lihat Wahbah Zuhaili, dkk,al-Qur'an Seven in One, terj. Imam Ghazali Masykur. dkk, (PT. Almahira: Jakarta, 2009), hal. 178.

$$
\begin{aligned}
& 22 \text { مَا سَلَكَكُمْ فِيْ سَقَرَ ، قَالْوُا لَمْ نَكُ مِنَ المُصَلِّينَ } \\
& \text { "Apakah yang memasukkan kamu ke }
\end{aligned}
$$
dalam Saqar (neraka)? Mereka menjawab: "Kami dahulu tidak termasuk orang-orang yang mengerjakan shalat." Lihat Wahbah Zuhaili, dkk, al-Qur'an Seven in One..., hal. 577.
"Dan dirikanlah shalat, tunaikan zakat dan rukuklah Bersama orangorang yang rukuk."23

Begitu juga dengan Piruza Puadi yang menyebutkan bahwa shalat itu penting bagi umat Islam. Karena shalat adalah tiang agama dan kewajiban yang tidak boleh ditinggalkan. Dengan shalat kita bisa membedakan mana yang muslim dan yang kafir. Selain itu, dengan melaksanakan shalat bisa menghindarkan diri dari perbuatan keji dan munkar. Informan ini menguatkan penjelasannya dengan membaca firman Allah pada QS. AlAnkabut/29: 45

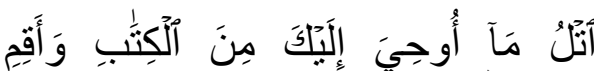

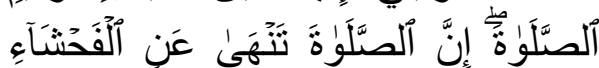

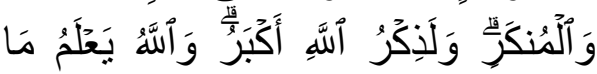
تَصْنَعُونَ "Bacalah apa yang telah diwahyukan kepadamu, yaitu Al Kitab (Al Quran) dan dirikanlah shalat. Sesungguhnya shalat itu mencegah dari (perbuatanperbuatan) keji dan mungkar. Dan sesungguhnya mengingat Allah (shalat) adalah lebih besar (keutamaannya dari ibadat-ibadat yang lain). Dan Allah mengetahui apa yang kamu kerjakan."

${ }^{23}$ Lihat Wahbah Zuhaili, dkk, al-Qur'an Seven in One..., hal. 5. 
Ayat ini difahami oleh dirinya sebagai perintah Allah kepada seorang muslim akan kewajiban shalat. Maka status hukum wajib, akan berdosa jika seseorang meninggalkannya. Bahwa shalat juga merupakan cara dan media komunikasi bagi kita untuk meminta, mengadu kepada Allah dan menjadi pembuktian bahwa kita termasuk orang yang taat dan menjalankan perintahNya. Ditambakan oleh informan lain, bahwa dengan bergabungnya dengan Komunitas Biker Muslim Bengkulu, ada sebuah keinginan dan semangat untuk berhijrah menjadi lebih baik bersama orangorang yang mau juga berhijrah. Dengan begitu, ada media dan komunikasi untuk saling mengingatkan dalam kebaikan termasuk agar terus istiqamah dalam proses menjadi seorang muslim yang taat kepada Allah.

Dari hasil wawancara, ada 2 ayat yang umumnya diketahui dan difahami sebagai dalil dalam pelaksanaan shalat yaitu QS. alBaqarah/2: 24 yang artinya: "Dan dirikanlah shalat, tunaikan zakat dan rukuklah Bersama orang-orang yang rukuk." dan QS. al-Ankabut/29: 45 yang artinya "...dan dirikanlah shalat. Sesungguhnya shalat itu mencegah dari (perbuatan-perbuatan) keji dan mungkar.."

Kedua ayat ini sebenarnya bukan hanya diketahui oleh anggota komunitas Biker Muslim Bengkulu dan atau informan penelitian, melainkan umumnya sebagian besar umat sudah akrab dengan ayat dimaksud. Ayat ini memang secara tekstual memberikan perintah kepada umat Islam agar melaksankan perintah shalat. Perintah utama yang tidak boleh ditinggalkan apapun alasannya. Karena shalat adalah penentu keberhasilan dan kebahagiaan seseorang nantinya di hari akhirat.

\section{b. Pemahaman dan Pengamalan} Ayat tentang zakat dan sedekah.

Berdasarkan observasi penulis sebelumnya, salah satu kegiatan yang dilakukan oleh komunitas Biker Muslim Bengkulu adalah berbagi. Berbagi yang dimaksud adalah komunitas ini menggalakkan kepada anggotanya untuk gemar bersedekah, menyisihkan sebagian harta untuk kebaikan seperti membantu pembanguna musholla atau 
masjid, peduli terhadap korban bencana dan musibah serta memberikan donasi kepada orang yang sakit.

Pelaksanaan kegiatan ini, tentunya berangkat dari pembacaan dan pemahaman dari nilai-nilai keagamaan yang mereka terima termasuk dari bacaan teks agama berupa ayat al-Qur'an. Dalil yang dimaksud tentunya menjadi sprit komunitas ini untuk berbagi dalam bidang sosial sebagai salah satu bentuk hijrah yang mereka fahami yaitu menjadi lebih baik dari sebelumnya dan bermanfaat bagi orang lain. Menurut Henli, bahwa bersedekah adalah hal yang penting juga bagi seorang muslim.

Menjadi bikers dengan semangat hijrah harus ditunjukkan juga dengan giat bersedekah. Maka dalam komunitas biker Muslim Bengkulu ini dianjurkan untuk bersedekah dan berinfak dari anggotanya. Infaq dan sedekah yang terkumpul akan disalurkan kepada mereka yang tertimpa musibah, baik musibah alam seperti banjir, kebakaran, serta berbagi kepada panti asuhan, panti jompo, fakir miskin termasuk masjid dan musholla yang sedang membutuhkan bantuan untuk renovasi. Salah satu ayat yang dijadikan dasar adalah QS. alBaqarah/2: 110. Allah berfirman:

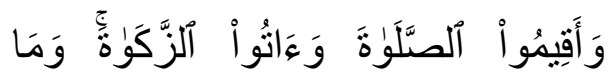

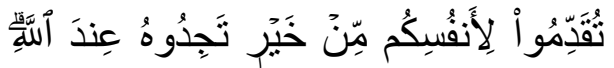

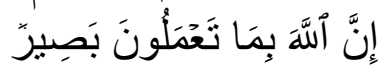

"Dan dirikanlah shalat dan tunaikanlah zakat. Dan kebaikan apa saja yang kamu usahakan bagi dirimu, tentu kamu akan mendapat pahala nya pada sisi Allah. Sesungguhnya Alah Maha Melihat apa-apa yang kamu kerjakan."

Informan lain menambahkan bahwa sedekah atau infaq adalah perintah dan perbuatan baik yang disukai Allah. Menjadi satu kebahagian baginya ketika bisa berbagi dan turut berkontribusi di saat komunitas biker muslim Bengkulu melakukan penggalangan dana dan membatu orang yang membutuhkan. Dengan bersedekah juga bisa melatih diri agar tidak menjadi orang yang pelit, sedangkan pelit itu adalah bisikan setan. Selanjutnya infroman menunjukkan surat al-Baqarah ayat 268 yaitu:

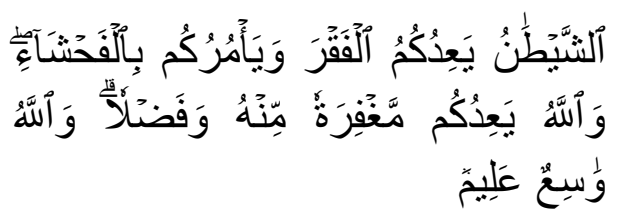


"Setan menjanjikan (menakut-nakuti) kemiskinan kepadamu dan menyuruh kamu berbuat keji (kikir), sedangkan Allah menjanjikan ampunan dan karunia-Nya kepadamu. Dan Allah Mahaluas, Maha Mengetahui."

Memahami sedekah dan infaq adalah perbuatan baik tentunya tidak semua orang bisa. Karena dalam kehidupan sosial, masih ada orang yang enggan berbagi, tidak peduli dan simpati terhadap apa yang dirasakan orang lain. Apa yang dia miliki dari harta difahami bahwa hartanya sendiri, tidak ada hak orang lain di dalamnya. Padahal Allah juga menegaskan dalam QS. al-Zariyat: 19 yang artinya "Dan Pada Harta-Harta Mereka Ada Hak Untuk Orang Miskin Yang Meminta Dan Orang Miskin Yang Tidak Mendapat Bagian."

Ketika komunitas ini punya aktivitas dan kegiatan untuk berbagi baik disebut infaq atau sedekah, maka ini perwujudan hijrah yang juga menjadi niscaya. Ayat yang disebutkan informan di atas memberikan informasi kepada semuanya bahwa seruan berinfaq itu memang nyata dan ada dari agama, karena perbuatan itu adalah baik, dan Allah mencintai orang-orang yang melakukan kebaikan.

c. Pemahaman dan Pengamalan Ayat tentang Persaudaraan.

Dalam komunitas Biker muslim Bengkulu juga terlihat nyata bahwa persaudaraan itu diikat atas dasar iman dan Islam serta semangat dalam berhijrah. Sehingga rasa persaudaraan itu juga dibuktikan dalam rangka menguatkan silaturrahim, dan menjaga semangat hijrah agar tetap istiqamah. Menjadi mafhum bagi hampir semua kita bahwa QS. al-Hujurat: 10 yang menyatakan sesungguhnya orang beriman itu bersaudara. ${ }^{24}$ Ayat ini sudah sering disampaikan dan diperdengarkan kepada umat Islam baik dalam moment pengajian, khutbah jum'at dan sebagainya. Dari wawancara penulis, informan penelitian menyebutkan ahwa persaudaraan dalam ikatan iman umumnya sudah menjadi pengetahuan, tapi dalam implementasinya tidak mudah untuk diwujudkan, bahkan sering terjadi perselisihan hingga

24 Abu Zaid, Nashr Hamid, Tekstualitas al-Qur'an, terj. Khoiron Nahdiyyin, Yogyakarta: LKIS, 2000. lihat Juga: Farhan, Ahmad, Living Qur'an Sebagai Metode alternative dalam Studi al-Qur'an, dalam Jurnal El Afkar, Vol. 6, Nomor II, Juli-Desember, 2017 
pengkotak-kotakan karena perbedaan bacaan, mazhab atau pemikiran.

Oleh karenanya, persaudaraan yang dibangun dalam komunitas Biker Muslim Bengkulu ini menjadi sinyal positif untuk meminimalisir perbedaan dan peduli sesama. Bahwa perbedaan itu menjadi niscaya berdasarkan skenario Allah. Kalaulah Allah berkehendak, maka akan dijadikan umat ini satu, ${ }^{25}$ tapi Allah menjadikan manusia berbeda beda untuk menjadi ujian siapa terbaik diantara mereka. Oleh karenanya, mengedepankah ukhwah demi kenyamanan dan kebaikan sesama menjadi keharusan daripada saling bersitegang karena perbedaan, meski mazhab berbeda ukhwah tetap utama.

Ayat ini juga yang menjadi inspirasi komunitas Biker Muslim Bengkulu untuk melakukan kegiatan-kegiatan peduli sosial dan sesama, baik sesama anggota komunitas, keluarga dan saudaranya serta terhadap orang lain. Hal ini dilihat dari kesadaran mereka untuk mendatangi orang lain yang mendapatkan musibah, mengunjungi orang sakit hingga memberikan bantuan rehab pembangunan masjid dan musholla. Pemahaman anggota komunitas untuk menujukkan kepedulian terhadap orang lain, mengedepankan rasa ukhwah dalam rangka berbagi adalah sebuah implikasi positif dari niat hijrah bersama komunitas. Begitulah nabi menegaskan bahwa orang beriman diibaratkan satu tubuh, yang jika salah satu anggota tubuhnya merasakan sakit, maka anggota tubuh lainnya akan merasakan hal yang sama.

Dalam hadis Bukhari Muslim yang diriwayatkan oleh $\mathrm{Nu}^{\prime}$ man bin Basyir:

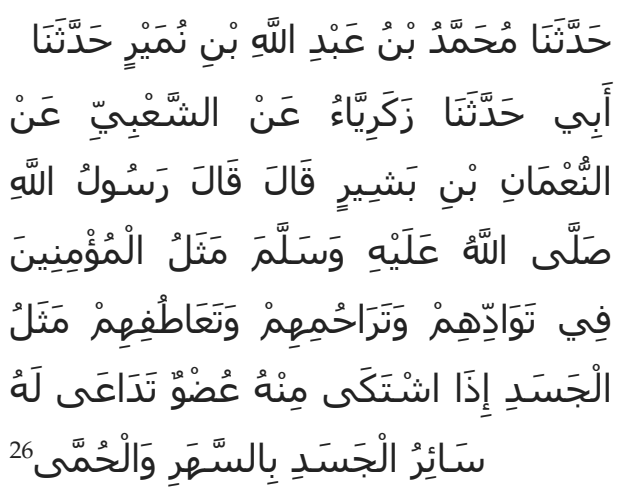

Bahwa persaudaraan dibangun atas dasar iman juga

25 Firly Annisa, Hijrah Milenial antara Kesalehan dan Populism, dalam Jurnal "Ma'arif Institut" Vol. 13, No. 1, Juni 2018, 
sejalan dengan persaudaraan atas Islam. Dalam hadis Bukhari yang diriwayatkan oleh Abdullah ibn Umar, nabi bersabda:

الْمُسْلِمُ أَخْو الْمُسْلِمِمِ لَا يَظْلْمُهُ وَلَا يُسْلِمُهُ، وَمَنْ كَانَ فِي حَاجََة أَخِيهِ كَانَ

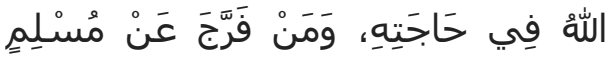

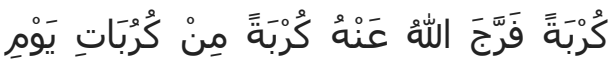

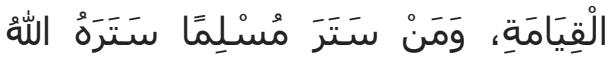

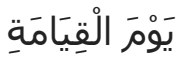

Seorang muslim itu saudara bagi muslim yang lainnya. Tidak boleh mendhaliminya dan tidak boleh pula menyerahkan kepada orang yang hendak menyakitinya. Barangsiapa yang memperhatikan kebutuhan saudaranya, maka Allah akan memperhatikan kebutuhannya. Barangsiapa yang melapangkan kesulitan seorang muslim, niscaya Allah akan melapangkan kesulitankesulitannya di hari kiamat. Dan barangsiapa yang menutupi kesalahan seorang muslim, niscaya Allah akan menutupi kesalahannya kelak di hari kiamat" (HR. Bukhari no. 2442, Muslim no. 2580, Ahmad no. 5646, Abu Dawud no. 4893, al--Tirmidzi no. 1426). 27

\section{Kesimpulan}

Berdasarkan rumusan penelitian, maka penelitian ini bisa disimpulkan:

1. Hijrah dalam pandangan komunitas Biker Muslim Bengkulu

\footnotetext{
${ }^{26} \mathrm{CD}$ Ensiklopedia Hadis, Sembilan Kitab Imam, Jakarta: Lidwa Pusaka, tt.

27 CD Ensiklopedia Hadis, Sembilan Kitab Imam, Jakarta: Lidwa Pusaka, tt.
}

yang tergali berdasarkan informan penelitian adalah perubahan, perpindahan dan kembali pulang. Perubahan yang dimaksud adalah perubahan dari sesuatu yang buruk kepada yang baik, dari maksiat kepada taat. Adapun perpindahan adalah perpindahan dari kebiasaan negatif kepada kebiasaan positif. Sedangkan kembali pulang berkonotasi meninggalkan kekufuran dan halhal yang tidak sesuai dengan ajaran agama dan berpulang ke jalan yang sebenarnya. Jika selama ini masih sering meninggalkan kewajiban-kewajiban seperti shalat, tinggkah laku yang tidak baik, berkata tidak benar dan berdusta, maka hijrah berarti merubah kebiasaan itu dengan berbicara yang benar dan jujur dalam perkataan.

2. Untuk pemaknaan hijrah dalam praktek keagamaan komunitas Biker Muslim Bengkulu, penulis membatasi pada aktivitas yang menjadi praktek hijrah komunitas biker Muslim Bengkulu. Pertama, pemaknaan terhadap shalat. Bahwa shalat adalah kewajiban utama dan perintah Allah. Informan mengungkapkan 
bahwa selama ini masih sering meninggalkan shalat. Dengan bergabungnya pada komunitas ini, semakin faham dan giat melaksanakan kewajiban shalat. Praktek ini juga berangkat dari pemaknaan QS. al-Baqarah/2: 43, QS. al-Ankabut/ 29: 45 . Kedua, pemaknaan terhadap berinfaq, sedekah dan zakat. Jika selama ini masih acuh terhadap kesulitan orang lain, enggan membantu dan berbagi kepada sesama, terjadi perubahan ekspresi dari anggota komunitas untuk memberikan bantuan baik berupa infaq, sedekah kepada sesama. Pemahaman bahwa dari harta ada hak orang lain, berinfaq sama dengan berinvestasi kebaikan yang disukai Allah menjadi bentuk praktek hijrah. Ketiga, pemaknaan terhadap ayat Persaudaraan. Pada ini juga yang menjadi inspirasi komunitas Biker Muslim Bengkulu untuk melakukan kegiatan-kegiatan peduli sosial dan sesama, baik sesama anggota komunitas, keluarga dan saudaranya serta terhadap orang lain. Hal ini dilihat dari kesadaran mereka untuk mendatangi orang lain yang mendapatkan musibah, mengunjungi orang sakit hingga memberikan bantuan rehab pembangunan masjid dan musholla. Pemahaman anggota komunitas untuk menujukkan kepedulian terhadap orang lain, mengedepankan rasa ukhwah dalam rangka berbagi adalah sebuah implikasi positif dari niat hijrah bersama komunitas. Begitulah nabi menegaskan bahwa orang beriman diibaratkan satu tubuh, yang jika salah satu anggota tubuhnya merasakan sakit, maka anggota tubuh lainnya akan merasakan hal yang sama.

\section{Referensi}

1. Chirzin, Muhammad dkk, Metodologi Penelitian Living al-Qur'an dan Hadis, ed Sahiron Syamsuddin, Yogyakarta: Teras, 2007.

2. Syamsudin, S., "Ranah-ranah Penelitian dalam Studi al-Qur'an dan Hadis" dalam M. Mansyur dkk., Metodologi Penelitian Living Qur'an dan Hadis, (Yogyakarta: TH. Press, 2007), hal. xiv.

3. Heddy Shri Ahimsa, The Living alQur'an: Beberapa Perspektif Antropologi, dalam Jurnal Walisongo, Volume 20, Nomor 1, Mei 2012, hal. 258.

4. Misbah, Muhammad, Living Qur'an di Instansi Kesehatan: Fenomena "Gerakan Membaca Al-Quran Sebelum Bekerja" di Rumah Sakit Islam Sultan Agung Semarang. OJS, "Hermeneutik" Jurnal Ilmiah Seputar Kajian al-Qur'an dan Tafsir, Prodi Ilmu al-Qur'an dan Tafsir 
STAIN

Kudus.

Lihat

di http://journal.stainkudus.ac.id.

5. Indriani, Dhita Prasanti dan Sri Seti, Konstruksi Makna Hijrah bagi Komunitas Let's Hijrah dalam Media Sosial Line, dalam "al-Izzah" Jurnal Hasil-hasil Penelitian, IAIN Kendari, Volume 14, Nomor 1 (Mei 2019).

6. Adi Bayu Mahadian, Annisa Novia Sari, Perilaku Komunikasi Pelaku Hijrah (Studi Fenomenologi Pelaku Hijrah dalam Shift Gerakan Pemuda Hijrah Kota Bandung), dalam " Jurnal Linimasa", FISIP UNPAS, Volume 1, Nomor 1, Januari 2018.

7. Amna, Afina, Hijrah Artis sebagai Komodifikasi Agama, dalam "Jurnal Sosiologi Reflektif", Prodi Sosiologi UIN Sunan Kalijaga Yogkarta, Volume 13, Nomor 2, April 2019.

8. Ratna, Nyoman Kutha, Teori, Metode, dan Teknik Penelitian Sastra: Dari Strukturalisme hingga Poststrukturalisme, Yogyakarta: Pustaka Pelajar, 2006.

9. Moleong, Lexy J, Metodologi Penelitian Kualitatif, Bandung: Remaja Rosyada Karya, 2005.

10. Suprayogo, Imam, Metodologi Penelitian Sosial-Agama, Bandung: Remana Rosyda Karya, 2003.

11. Rafiq, Ahmad, Pembacaan yang atomistic terhadap al-Qur'an Antara Penyimpangan dan Fungsi, Jurnal Studi Ilmu al-Qur'an dan Hadis, Vol. 5, No. 1 Januari 2004

12. Tim

Penyusun, Ensiklopedia Islam, (Jakarta: PT. Ichtiar Baru van Hoeve, 2001.

13. Wahbah Zuhaili, dkk, al-Qur'an Seven in One, terj. Imam Ghazali Masykur. dkk, (PT. Almahira: Jakarta, 2009), hal. 178.

14. Abu Zaid, Nashr Hamid, Tekstualitas al-Qur'an, terj. Khoiron Nahdiyyin, Yogyakarta: LKIS, 2000.

15. Farhan, Ahmad, Living Qur'an Sebagai Metode alternative dalam Studi
al-Qur'an, dalam Jurnal El Afkar, Vol.

6, Nomor II, Juli-Desember, 2017

16. Firly Annisa, Hijrah Milenial antara Kesalehan dan Populism, dalam Jurnal "Ma'arif Institut" Vol. 13, No. 1, Juni 2018,

17. CD Ensiklopedia Hadis, Sembilan Kitab Imam, Jakarta: Lidwa Pusaka, tt.

18. Satori, Djam'an dan Aam Komariah, Metodologi Penelitian Kualitatif, Bandung: Alfabeta, 2013. 